\title{
ANALISIS STRATEGI PENINGKATAN KINERJA PERUSAHAAN DENGAN PENDEKATAN SWOT-BALANCED SCORECARD PADA PT. IPSI KARYA ABADI
}

\author{
Arie Pratikno \\ Program Studi Magister Manajemen Universitas Tarumanagara \\ ariuntar30@gmail.com \\ Mukti Rahardjo \\ Program Studi Magister Manajemen Universitas Tarumanagara
}

Masuk : 06-06-2020, revisi : 25-06-2020 diterima untuk diterbitkan : 25-06-2020

\begin{abstract}
This study aims to test the performance of the company PT. IPSI Karya Abadi as measured by using the Balanced Scorecard approach and the company's performance improvement strategy in developing PT. IPSI Karya Abadi. This study uses a Balanced Scorecard analysis for performance measurement and SWOT analysis to determine strategy. The results of the analysis state that the results of performance measurements of financial perspectives, NPM in 2017 -2019 has increased, ROE in 2017-2019 has fluctuated, ROI in 2017-2019 has also fluctuated. The results of the customer satisfaction survey showed $69.27 \%$ so the data showed that satisfaction was in the high category. Customer retention test results show a decrease from year to year. The results of customer acquisition show fluctuations. Internal business process perspective, in the innovation process there is no latest innovation program from PT. IPSI Karya Abadi. The operation process is efficient, consistent and timely, and serves 24 hours. Learning and growth perspective, the employee satisfaction measure $79.65 \%$ in the high category and employee retention from 2017-2019 continues to increase.
\end{abstract}

Keywords: Company Performance, Strategy, Balanced Scorecard, SWOT

Abstrak: Penelitian ini bertujuan untuk menguji kinerja perusahaan PT. IPSI Karya Abadi yang diukur dengan menggunakan pendekatan Balanced Scorecard serta strategi peningkatan kinerja perusahaan dalam mengembangkan PT. IPSI Karya Abadi. Penelitian ini menggunakan analisis Balanced Scorecard untuk pengukuran kinerja dan analisis SWOT untuk menentukan strategi. Hasil analisis menyatakan bahwa hasil pengukuran kinerja perspektif keuangan, NPM pada 2017 -2019 telah meningkat, ROE pada 2017-2019 telah berfluktuasi, ROI pada 20172019 juga telah berfluktuasi. Perspektif pelanggan hasil survei kepuasan pelanggan menunjukkan 69,27\% sehingga data menunjukkan bahwa kepuasan berada dalam kategori tinggi. Hasil uji retensi pelanggan menunjukkan penurunan dari tahun ke tahun. Hasil akuisisi pelanggan menunjukkan fluktuasi. Perspektif proses bisnis internal, dalam proses inovasi tidak ada program inovasi terbaru dari PT. IPSI Karya Abadi. Proses operasi efisien, konsisten dan tepat waktu, dan melayani 24 jam. Perspektif pembelajaran dan pertumbuhan, ukuran kepuasan karyawan 79,65\% dalam kategori tinggi dan retensi karyawan dari 2017-2019 terus meningkat.

Kata Kunci: Kinerja Perusahaan, Strategi, Balanced Scorecard, SWOT

\section{PENDAHULUAN}

Salah satu perusahaan yang berjalan di industri kontruksi listrik sejak lama adalah PT. IPSI Karya Abadi. PT. IPSI Karya Abadi didirikan sejak pada tahun 1992 di Kota Semarang Jawa Tengah berkecimpung di bidang jasa kontruksi Mechanical Electrical. Pada awal berdiri PT. IPSI Karya Abadi fokus dalam melayani jasa Maintenance Transformator untuk kebutuhan industri.

Didukung dengan fasilitas perbengkelan yang lengkap serta sumber daya manusia yang berpengalaman, handal, dan terlatih. PT. IPSI Karya Abadi telah mampu melayani permintaan 
pelanggan dari berbagai sektor industri properti dan pertambangan baik pemerintah maupun swasta dengan jangkauan kerja mulai dari pulau Jawa, Sulawesi, Kalimantan, Sumatra, Batam, Bali, dan berbagai daerah lain di Indonesia.

Semakin berkembangnya industri jasa kontruksi listrik membuat PT. IPSI Karya Abadi kurang bisa bertahan dengan persaingan pada industri tersebut. Untuk menghadapi persaingan yang semakin ketat ini, setiap perusahaan dituntut untuk melakukan beberapa program peningkatan manajemen, penghematan biaya tanpa mengurangi pelayanan kepada client agar memiliki daya saing untuk berkompetisi.

Salah satu yang penting bagi perusahaan adalah untuk memperhartikan manajemen perusahaan. Hal tersebut bisa dilakukan dengan melakukan pengukuran kinerja. Seharusnya perusahaan mengukur kinerja perusahaanya dalam periode tertentu sehingga perusahaan dapat mengevaluasi kinerja dari perusahaannya sehingga perusahaan dapat meningkatkan kinerjannya untuk lebih unggul daripada perusahaan pesaing lainnya dan perusahaan dapat bertahan di tengah perkembangan saat ini. Robert Behn (2003) melakukan penelitian dan menyatakan jika pengukuran kinerja perlu dilakukan untuk membantu manjerial perusahaan berupa mengevaluasi kinerja, mengontrol kinerja karyawan, mengatur anggaran, memotivasi karyawan, penentuan promosi jabatan, mencapai tujuan perusahaan, mempelajari kesalahan yang pernah dilakukan, serta meningkatkan kinerja.

Dalam melakukan pengukuran kinerja perusahaan diperlukan beberapa aspek-aspek. Namun, biasanya perusahaan hanya mengukur kinerja perusahaan hanya dari aspek finansial atau laporan keuangannya. Pasahal aspek finansial ini hanya mengevaluasi kejadian kesalahan yang telah terjadi dan tidak dapat mengelola kinerja perusahaan secara langsung agar lebih baik. Pada perkembangan industry sekarang ini, pengukuran kinerja dari aspek nonfinansial harus atau wajib dilakukan untuk mengetahui kinerja baik internal ataupun eksternal perusahaan tersebut. Jika perusahaan hanya mengukur kinerja perusahaan berdasarkan aspek finansialnya saja, maka perusahaan tidak mempunyai pengukuran atau indikator yang dapat ditinjau untuk dievaluasi.

Salah satu alat pengukuran kinerja yang sudah banyak digunakan oleh perusahaanperusahaan adalah Balanced Scorecard (BSC). Balanced Scorecard (BSC) merupakan salah satu alat perancangan strategi yang mampu menyatukan perspektif yang ada untuk mencapai visi yang diinginkan perusahaan. Balanced Scorecard adalah kartu skor yang digunakan untuk mengukur kinerja dengan memperhatikan keseimbangan antara sisi keuangan dan nonkeuangan, antara jangka pendek dan jangka panjang serta melibatkan faktor internal dan eksternal (Mubarok, 2018).

Berdasarkan uraian diatas maka penulis tertarik untuk melakukan penelitian yang berjudul "Analisis Strategi Peningkatan Kinerja Perusahaan dengan Pendekatan SWOTBalanced Scorecard pada PT. IPSI Karya Abadi”.

\section{METODOLOGI PENELITIAN}

Dalam penelitian ini, peneliti menggunakan metode deskriptif, yaitu suatu metode penelitian yang dilakukan untuk memperoleh gambaran mengenai keadaan yang terjadi pada masa sekarang. Terkait dengan hal tersebut Hadari (2015) mengemukakan bahwa metode deskriptif dapat diartikan sebagai prosedur pemecahan masalah yang diselidiki dengan menggambarkan/melukiskan keadaan subyek/objek penelitian (seseorang, lembaga, masyarakat dan lain-lain) pada saat sekarang berdasarkan fakta-fakta yang tampak atau sebagaimana adanya. Adapun yang menjadi tujuan dalam penelitian ini adalah untuk mengetahui deskriptif umum tentang strategi peningkatan kinerja perusahaan PT. IPSI Karya Abadi untuk mengembangkan usaha tersebut. metode pengumpulan data yang digunakan antara lain studi pustaka dan studi lapangan berupa dokumentasi, wawancara untuk analisis SWOT, serta kuesioner untuk pengukuran perspektif pelanggan dan perspektif pertumbuhan pembelajaran. Metode analisis yang digunakan dalam penelitian ini adalah analisis SWOT 
yang dilakukan melalui dua tahap yaitu analisis eksternal dan internal serta analisa balanced scorecard. Pengukuran kinerja dengan balanced scorecard didasarkan pada empat perspektif antara lain perspektif keuangan, perspektif pelanggan, perspektif proses internal bisnis, serta perspektif pertumbuhan dan pembelajaran.

\section{ANALISIS DAN BAHASAN TEMUAN}

\section{Pengukuran Kinerja Perusahaan PT. IPSI Karya Abadi dengan Menggunakan Pendekatan Balanced Scorecard}

\section{Perspektif Keuangan}

Berdasarkan perhitungan 1 dapat diketahui bahwa Net Profit Margin pada tahun 2017 ke 2018 mengalami peningkatan, Net Profit Margin (NPM) pada tahun 2017 sebesar 3\% meningkat menjadi 5,66\% pada tahun 2018. Peningkatan ini disebabkan karena pajak yang dibayar perusahaan menurun. Kejadian ini secara tidak langsung telah mempengaruhi laba bersih yang diperoleh perusahaan, yang pada akhirnya mengakibatkan peningkatan laba bersih, meskipun biaya lainnya mengalami peningkatan.

Net Profit Margin (NPM) pada tahun 2019 juga mengalami peningkatan, dimana pada tahun 2018 sebesar 5,66\% dan meningkat pada tahun 2019 sebesar 5,96\%. Peningkatan ini disebabkan karena menurunnya biaya lain-lainnya dan bunga bank, sehingga tidak langsung mempengaruhi laba bersih yang diperoleh perusahaan.

Dengan demikian Net Profit Margin (NPM) pada tahun 2017 sampai dengan 2019 mengalami peningkatan walaupun hanya sedikit, sehingga agar Net Profit Margin (NPM) PT. IPSI Karya Abadi terus mengalami peningkatan maka sebaiknya perusahaan meminimalkan biaya lain-lain, mengurangi hutang perusahaan, dan meningkatkan pendapatan atau penjualan perusahaan.

Pada tahun 2017 ke tahun 2018 nilai ROE mengalami peningkatan, dimana pada tahun 2017 nilai ROE sebesar 5,06\% dan meningkat pada tahun 2018 sebesar 9,41\%. Dengan demikian dapat dikatakan bahwa perusahaan telah meminimalisir dalam penggunaan ekuitas atau modal yang dimiliki perusahaan sehingga meningkatnya nilai ROE.

Sementara ROE pada tahun 2018 ke tahun 2019 mengalami penurunan. ROE pada tahun 2018 sebesar 9,41\% dan menurun di tahun 2019 menjadi sebesar 8,34\%. Penurunan ini disebabkan karena menurunya laba bersih perusahaan dengan meningkatnya modal atau ekuitas yang dimiliki perusahaan. Dengan menurunnya nilai ROE resiko pengembalian hutang bank mengalami peningkatan dan laba bersih menjadi menurun.

Dengan demikian ROE dari tahun 2017 sampai dengan 2019 mengalami fluktuasi, agar tahun- tahun berikutnya ROE mengalami tidak mengalami fluktuasi lagi, namun mengalami peningkatan sebaiknya perusahaan mampu menggunakan modal perusahaan sebaik mungkin agar dapat memberikan hasil yang baik sehingga dapat meningkatkan laba bersih perusahaan.

ROI pada tahun 2017 ke tahun 2018 mengalami peningkatan. ROI pada tahun 2017 sebesar 3,02\% dan meningkat pada tahun 2018 sebesar 6,08\%. Peningkatan ini disebabkan oleh meningkatnya laba bersih serta aset perusahaan. Hal ini menggambarkan bahwa aset dapat dimanfaatkan oleh perusahaan dengan efisien untuk meningkatkan laba bersih.

Sedangkan ROI pada tahun 2018 ke tahun 2019 mengalami penurunan. ROI pada tahun 2018 sebesar 6,08\% turun menjadi 5,68\% pada tahun 2019. Penurunan disebabkan karena laba bersih yang menurun dan tidak sebanding dengan peningkatan aset. Hal ini menyebabkan peningkatan aset yang tidak diikuti dengan meningkatnya laba bersih telah menimbulkan ketidakefisienan (terjadi pemborosan) dalam pemanfaatan aset 
perusahaan.

Dengan demikian ROI pada tahun 2017 sampai dengan 2019 mengalami fluktuasi, agar tahun-tahun berikutnya ROI tidak mengalami fluktuasi dan mengalami peningkatan sebaiknya perusahaan mampu memaksimalkan pemanfaatan modal sendiri secara efisien sehingga dapat meningkatkan laba bersih.

2. Perspektif Pelanggan

Berdasarkan hasil survei kepuasan pelanggan tersebut menunjukkan angka 69,27\% angka ini dapat dikategorikan tinggi yang artinya sebanyak 69,27\% setuju responden atas pernyataan yang diajukan melalui kuesioner.

Hasil uji retensi pelanggan yang dilakukan kepada perusahaan PT. IPSI Karya Abadi menunjukkan adanya penurunan dari tahun ketahun. Artinya, hasil uji tersebut menunjukan bahwa manajemen sudah melakukan pendekatan yang baik terhadap pelanggannya atau pengguna jasanya sehingga perusahaan dapat mempertahankan para konsumennya.

Hasil uji akuisisi pelanggan yang dilakukan kepada PT. IPSI Karya Abadi menunjukkan adanya fluktuasi peningkatan pada tahun 2018 dan penurunan terjadi di tahun 2019. Artinya, hasil uji tersebut menunjukan bahwa kinerja manajemen mengalami penurunan dalam mendapatkan konsumen baru.

3. Perspektif Internal Bisnis

PT. IPSI Karya Abadi sebagai perusahaan besar tentu tidak akan berhenti dalam pengembangan produk-produk baru agar dapat terus bersaing, melalui proses inovasi PT. IPSI Karya Abadi telah menjalankannya dengan baik. Namun, proses internal bisnis belum ada yang diterapkan oleh PT. IPSI Karya Abadi. Padahal internal proses perusahaan sangat penting dalam persaingan perusahaan yang ketat sat ini.

Proses operasi yang dilakukan PT. IPSI Karya Abadi bukan hanya menerapkan strategi integrasi dari hulu ke hilir saja, tetapi juga menajamkan tiaptiap strategi itu secara detail melalui beberapa implementasi, yaitu: pola kerjasama dalam bentuk penyedia jasa pengelolaan proyek, dan penyedian produk. Dalam focus kinerjanya PT. IPSI Karya Abadi juga menitikberatkan kepada penyampaian produk dan jasa kepada pelanggan yang ada secara efisien, konsisten dan tepat waktu. PT. IPSI Karya Abadi juga melakukan berbagai layanan purna jual untuk tetap menjaga hubungan dengan para kliennya antara lain berupa menerima pengaduan 1 X 24 jam dan bisa melalui jaringan telepon atau web.

4. Perspektif Pembelajaran dan Pertumbuhan

Hasil kuesioner menunjukkan bahwa kepuasan karyawan sebesar 79,65\%. Berdasarkan kategori tingkat kepuasan maka kepuasan karyawan masuk dalam kategori setuju tetapi sangat mendekati kategori di atasnya yaitu sangat setuju. Hal ini patut menjadi bahan evaluasi perusahaan karena kepuasan karyawan ini mempengaruhi kinerja karyawan.

Kepuasan karyawan juga dapat ditinjau dari retensi karyawan. Semakin sedikit karyawan yang keluar maka semakin kecil angka retensi. Sehingga dapat dipahami bahwa semakin kecil angka retensi karyawan maka semakin baik. Dari hasil pengukuran retensi karyawan, menunjukkan ditahun 2017 terdapat 4 karyawan keluar dari total 30 karyawan yaitu sebesar $13,33 \%$. Pada tahun 2018, terdapat karyawan yang keluar yaitu sebanyak 5 karyawan dari total 29 karyawan sehingga angka retensi yaitu sebesar $17,24 \%$.

Pada tahun 2019 terdapat 5 karyawan yang keluar sehingga menghasilkan angka retensi sebesar 19,23\% yang mana angka tersebut terbilang cukup besar dibandingkan dengan tahun lainnya. Hal ini dapat terjadi karena sejumlah karyawan baru ditahun sebelumnya yang merasa ketidakcocokan dengan perusahaan. 


\section{Strategi Peningkatan Kinerja Perusahaan dalam Mengembangkan PT. IPSI Karya Abadi}

Berikut merupakan matrik SWOT yang didasarkan pada wawancara yang dilakukan dengan Direktur PT. IPSI Karya Abadi.

\section{Tabel 1}

Matrik SWOT

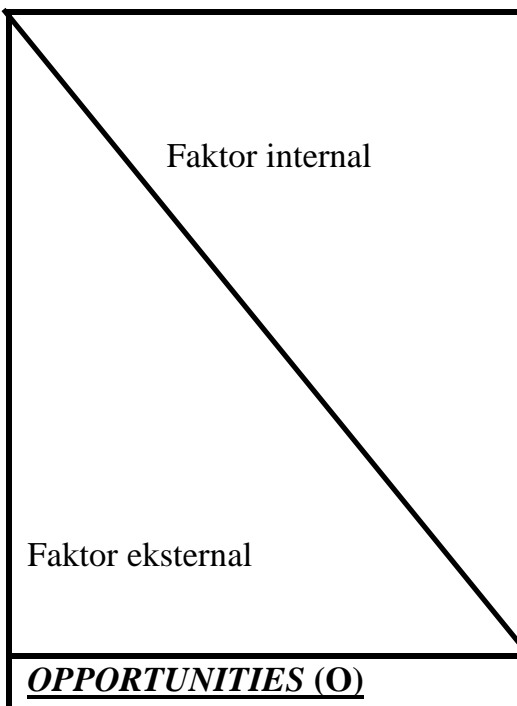

1. Banyak investor yang tertarik di bidang perusahaan jasa seperti PT. IPSI Karya Abadi

2. Perusahaan seperti PT. IPSI Karya Abadi sangat diperlukan sehari-harinya oleh masyarakat

3. Karyawan mulai menciptakan regenerasi

\section{STRENGTH (S)}

1. Keuangan PT. IPSI Karya Abadi saat ini dibilang cukup baIk karena beban oprasional tidaklah besar dibandingkan dengan perusahaan besar

2. Konsumen PT. IPSI Karya Abadi karya abadi terbilang cukup luas dan mejangkau sampai ke luar jawa

3. PT. IPSI Karya Abadi bersifat repeat order customer lama dan menambah customer baru.

4. Karyawan PT. IPSI Karya Abadi tidaklah banyak karena belum melangkah ke produksi

1. Membuat perusahaan lebih besar dengan menarik investor untuk menanamkan modal di PT. IPSI Karya Abadi

2. PT. IPSI Karya Abadi membuat strategi pemasaran agar masyarakat lebih memilih PT. IPSI Karya Abadi dibandingkan dengan perusahaan lainnya.

3. Mengembangkan karyawan dengan dilakukannya pelatihan serta menambah karyawan yang lebih muda dan memiliki pengalaman yang luas

\section{Strategi WO}

1. Mencari investor yang bersedia menanamkan modal di PT. IPSI Karya Abadi

2. Menerapkan program akutansi agar keuangan perusahaan dapat dievaluasi

3. Melakukan promosi melalui media sosial dan brosur untuk disebar dijalanan

4. Menjaga keselamatan karyawan dengan melakukan evaluasi saat bekerja

5. Dilakukan penilaian kinerja setiap bulannya untuk menilai produktifitas karyawan

\section{Strategi ST}

1. Keuangan perusahaan terlalu tergantung oleh pinjaman bank

2. Banyaknya pesaing dengan perusahaan yang lebih besar di bidang yang sama

3. Karyawan yang ceroboh dalam bekerja membuat nilai perusahaan negatif

4. Kurangnya regenarasi pada karyawan
1. Mencari modal lain selain pinjaman dari bank seperti modal dari investor atau lainnya

2. Memperluas pemasaraan

3. Menerapkan peraturan dalam keselamatan kerja

4. Melakukan rekruitmen karyawan yang telah berpengalaman dalam bidang yang sama

\section{Strategi WT}

1. Perusahaan dapat meningkatkan laba dengan mencari konsumen lebih banyak lagi

2. Melakukan promosi agar setiap tahunnya terdapat peningkatan pada jumlah konsumen

3. Melakukan evaluasi kinerja karyawan serta memberikan pelatihan pada karyawan lainnya

Inisiatif strategi akan dibahas berdasarkan tujuan atau sasaran strategis dengan masingmasing ukurannya antara lain menarik investor untuk menanamkan modal di PT. IPSI Karya Abadi, menerapkan program akutansi agar keuangan perusahaan dapat dievaluasi, meningkatkan pendapatan perusahaan, meningkatkan kepuasan pelanggan, memperluas pasar yang dijangkau, melakukan promosi melalui media sosial dan brosur untuk disebar dijalanan, prosedur pemesanan yang lebih baik, meningkatkan kepuasan kerja karyawan, meningkatkan kompetensi karyawan, dan meningkatkan kinerja karyawan. 


\section{KESIMPULAN}

Berdasarkan analisis dan pembahasan temuan yang telah dijelaskan diatas maka dapat ditarik kesimpulan bahwa:

1. Kinerja perusahaan diukur dari 4 perspektif, hasil pengukuran kinerja perspektif keuangan, NPM pada 2017 -2019 telah meningkat, ROE pada 2017-2019 telah berfluktuasi, ROI pada 2017-2019 juga telah berfluktuasi. Perspektif pelanggan hasil survei kepuasan pelanggan menunjukkan 69,27\% sehingga data menunjukkan bahwa kepuasan berada dalam kategori tinggi. Hasil uji retensi pelanggan menunjukkan penurunan dari tahun ke tahun. Hasil akuisisi pelanggan menunjukkan fluktuasi. Perspektif proses bisnis internal, dalam proses inovasi tidak ada program inovasi terbaru dari PT. IPSI Karya Abadi. Proses operasi efisien, konsisten dan tepat waktu, dan melayani 24 jam. Perspektif pembelajaran dan pertumbuhan, ukuran kepuasan karyawan 79,65\% dalam kategori tinggi dan retensi karyawan dari 2017-2019 terus meningkat.

2. Strategi peningkatan kinerja perusahaan dalam mengembangkan PT. IPSI Karya Abadi antara lain menarik investor untuk menanamkan modal di PT. IPSI Karya Abadi, menerapkan program akutansi agar keuangan perusahaan dapat dievaluasi, meningkatkan pendapatan perusahaan, meningkatkan kepuasan pelanggan, memperluas pasar yang dijangkau, melakukan promosi melalui media sosial dan brosur untuk disebar dijalanan, prosedur pemesanan yang lebih baik, meningkatkan kepuasan kerja karyawan, meningkatkan kompetensi karyawan, dan meningkatkan kinerja karyawan.

\section{REFERENSI}

Behn, R. D. (2003). Why measure performance? Different purpose required different measures. Harvard University, Public Administration Review, 63(5).

Mubarok, U. S. (2018). Penerapan SWOT Balanced Scorecard pada Perencanaan Strategi Bisnis. Surabaya: PT. Jakad Publishing.

Srimindarti, C. (2004). Balanced scorecard sebagai alternatif untuk mengukur kinerja. Fokus Ekonomi, 3(1).

Sudibyo, B. (1997). Pengukuran kinerja perusahaan dengan balance scorecard: bentuk, mekanisme, dan prospek aplikasinya pada BUMN. JEBI, 12(2), 35-49.

Kaplan, R. S. \& Norton, D. P. (1996). Balanced Scorecard, Menerjemahkan Strategi Menjadi Aksi, Alih Bahasa: Peter R. Yosi Pasla. Jakarta: Erlangga.

Nawawi, H. (2015). Metode Penelitian Bidang Sosial. Yogyakarta: Gajah. Mada University Press. 